\title{
Towards a Reflexive Turn in the Governance of Global Environmental Expertise The Cases of the IPCC and the IPBES
}

Silke Beck, Maud Borie, Jason Chilvers, Alejandro Esguerra, Katja Heubach, Mike Hulme, Rolf Lidskog, Eva Lövbrand, Elisabeth Marquard, Clark Miller, Tahani Nadim, Carsten Nesshoever, Josef Settele, Esther Turnhout, Eleftheria Vasileiadou and Christoph Goerg

\section{Linköping University Post Print}

\section{Tweet}

N.B.: When citing this work, cite the original article.

Original Publication:

Silke Beck, Maud Borie, Jason Chilvers, Alejandro Esguerra, Katja Heubach, Mike Hulme, Rolf Lidskog, Eva Lövbrand, Elisabeth Marquard, Clark Miller, Tahani Nadim, Carsten Nesshoever, Josef Settele, Esther Turnhout, Eleftheria Vasileiadou and Christoph Goerg, Towards a Reflexive Turn in the Governance of Global Environmental Expertise The Cases of the IPCC and the IPBES, 2014, GAIA, (23), 2, 80-87.

http://dx.doi.org/10.14512/gaia.23.2.4

Copyright: Oekom Verlag http://www.oekom.de/

Postprint available at: Linköping University Electronic Press http://urn.kb.se/resolve?urn=urn:nbn:se:liu:diva-108181 


\title{
Towards a Reflexive Turn in the Governance of Global Environmental Expertise
}

\author{
The Cases of the IPCC and the IPBES
}

Silke Beck, Maud Borie, Jason Chilvers, Alejandro Esguerra, Katja Heubach, Mike Hulme, Rolf Lidskog, Eva Lövbrand, Elisabeth Marquard, Clark Miller, Tahani Nadim, Carsten Neßhöver, Josef Settele, Esther Turnhout, Eleftheria Vasileiadou, Christoph Görg
The role and design of global expert organizations such as the Intergovernmental Panel on Climate Change (IPCC) or the Intergovernmental Platform on Biodiversity and Ecosystem Services (IPBES) needs rethinking. Acknowledging that a one-size-fits-all model does not exist, we suggest a reflexive turn that implies treating the governance of expertise as a matter of political contestation.

Towards a Reflexive Turn in the Governance of Global Environmental Expertise. The Cases of the IPCC and the IPBES GAIA 23/2 (2014): 80-87 | Keywords: assessment, environmental governance, expert organizations, IPBES, IPCC, science-policy interface, scientific advice

W hen international organizations are compelled to respond to ever more complex problems such as global warming and the loss of biodiversity, knowledge and expertise likewise become increasingly significant resources (Lövbrand forthcoming, Lidskog and Sundqvist 2011). The growing demand for policy-relevant knowledge has led to, or at least supported the growth of, a novel group of global expert organizations. ${ }^{1}$ Their defining characteristic is that they are entrusted with the task of reviewing and assessing the most recent scientific information produced worldwide that is relevant to an understanding of environmental change in relation to policy-relevant problems. This expertise, referred to as an assessment, can be seen as a form of second-order knowledge production. It is complementary to forms of first-order knowledge production in traditional science because such assessments articulate the highly distributed and disaggregated assortment of relevant scientific research and publications.

The Intergovernmental Panel on Climate Change (IPCC) and the Intergovernmental Platform on Biodiversity and Ecosystem Services (IPBES) provide excellent examples through which to explore the choices and options available when it comes to the governance of global expertise. The IPCC has just published its Fifth

Contact: Dr. Silke Beck (corresponding author) | Helmholtz Centre for Environmental Research - UFZ | Permoserstr. 15 | 04318 Leipzig | Germany | Tel.: +49341235173 | E-Mail: silke.beck@ufz.de

(C) 2014 S. Beck et al.; licensee oekom verlag.

This is an Open Access article distributed under the terms of the Creative Commons Attribution License (http://creativecommons.org/licenses/by/3.0), which permits unrestricted use, distribution, and reproduction in any medium, provided the original work is properly cited.
Assessment Report $(A R 5)^{2}$. The panel is recognized as a pioneer in providing policy-relevant science to global policy: It has conducted the most comprehensive orchestration of scientific knowledge to date and has managed to include experts from around the world in policy advice activities. In doing so it has spoken on behalf of global science with one voice, thereby acquiring a reputation as the epistemic authority in matters of climate policy. It was jointly awarded the 2007 Nobel Peace Prize along with former US Vice President Al Gore. The 2007 IPCC assessment report had already signaled that controversies over the existence of global warming have effectively been settled and that human influences on the climate system are real and significant (IPCC 2007). The IPCC has thus accomplished a core part of its original mission, namely to provide sound scientific evidence about the causes of human-induced global climate change. However, many of the characteristics and consequences of future climate change at sub-global scales, as well as their interactions with other drivers of change in the world, are still poorly understood. Because much has changed since the establishment of the IPCC in the late 1980s, discussions about the panel's future beyond 2014 are back on the agenda of the IPCC plenary sessions (Stocker 2013).

\footnotetext{
1 It is worth noting that there is a new global body for expert knowledge being formed to serve the UN Convention on Combating Drought and Desertification and also a new scientific advisory body, the UN Scientific Advisory Board (SAB), created by UN Secretary-General Ban Ki-moon in January 2014 (SAB 2014). This shows that the questions we raise have a wider significance beyond the IPCC and IPBES.

2 www.ipcc.ch/report/ar5
} 
Due to its achievements it has also been referred to in many spheres - including biodiversity and food security - as a model for organizing expert committees (Loreau et al. 2006). One example is the recently founded IPBES. Its establishment was preceded by negotiations over its institutional design, which went on for several years. The platform was set up in 2012 as a permanent intergovernmental science-policy organization in order to build upon and further the work of the Millennium Ecosystem Assessment (MEA 2005). Its second plenary session (IPBES-2) held in Antalya, Turkey, in December 2013, adopted the Antalya Consensus which notably contains the initial - ambitious - work program for the period 2014 to 2018.

In the following we discuss the responsiveness and organizational reflexivity of both panels. In the first part of this commentary, we explore the case of the IPCC. The second part focuses on the IPBES. The IPCC and the IPBES are at different stages in their development, and they differ in their mandate, scope and political contexts. Notwithstanding these differences, both face comparable challenges situated at the interface between science, public policy and global publics. ${ }^{3}$ In this commentary we briefly illustrate how the IPCC and IPBES have responded to particular challenges such as to demands for political relevance, the integration and representation of diverse and distributed knowledge and calls for public accountability and participation. We take these three challenges as a thematic direction for the discussion that follows. This enables us to highlight similarities and differences as well as points of convergence and divergence between them, leading to a consideration of path dependency and avenues for potential mutual learning processes between the IPCC and IPBES.

We also elaborate on the choices, room for maneuver and options that are available when designing or reforming global expert organizations. Indeed, the fact of this being a "choice" at all is often exactly the point at issue. The value lies more in opening up appreciations of choice than in closing these down (Stirling 2010). These choices concern the criteria for, inter alia, evaluating scientific evidence, setting standards for knowledge validity, selecting experts, organizing review procedures, and demarcating mandates between scientific and political institutions (Jasanoff 2012). The reflexive turn differs from prevailing approaches to the institutional design of expert organizations in two constitutive features. First, it calls attention to their epistemological and normative frameworks and thus, second, it opens up a space to consider and evaluate the full range of alternative institutional design options as opposed to implementing a one-size-fits-all model of expertise. The normative criteria underpinning our own approach derive from debates in science and technology studies (STS) con-

3 Boundary organizations are characterized by the fact that they are able to take on both academic as well as policy-related tasks. Given multiple forms of accountability and participation, they face the challenge of taking into account the heterogeneous expectations of their different audiences: They have to reconcile political demands, such as for geopolitical representativeness and public accountability, with the need for expert decision-making and integrity. cerning the democratic accountability of science policy. Taking our lead from this tradition, key is to import notions of delegation, accountability, and representation into the analysis and negotiation of expert decision-making (Jasanoff 2012, Miller 2009, Stirling 2010, Wynne 2007).

\section{IPCC: Closing Down to Process and Procedures}

Scientific assessment bodies are now established as a significant part of global environmental governance and exercise a remarkable amount of epistemic and political authority. The joint award of the 2007 Nobel Peace Prize to the IPCC is evidence of this. The way global expert organizations frame environmental problems determines what exactly the "problem" is that needs to be assessed and "resolved". Therefore, then, we also pay attention to processes of framing and re-framing issues, given that these processes in turn serve to shape and constrain the potential solutions. For example, in the case of the IPCC, "global average temperature" has long been the organizing device around which both scientific knowledge has been assessed and different policy options evaluated. Framing global climate change as a universal risk that demands collective action serves to underscore the need for consensus-based knowledge production and decision support. It has been difficult, if not impossible, for the IPCC to break away from the early framing of climate change around global average temperature as the pre-eminent indicator of risk. ${ }^{4}$

As a result, the political discussions about climate change along with popular perceptions of "global warming" - have become unnecessarily selective and restrictive. The range of policy choices that are compatible with the current range of scientific findings is narrowed down to improving climate predictions and creating new economic policy instruments (Reisinger 2011), thus neglecting a large number of policy alternatives including adaptation (Prins et al. 2010). This has been shown to be problematic in the international political sphere.

The IPCC has also largely failed to engage with alternative forms of expertise such as local knowledge (Ford et al. 2012), or to evaluate and facilitate more radical forms of civic action (e. g., Jamison 2010). This has closed off some forms of political response, with some arguing that climate change has become a "post-political" technocratic issue which limits opportunities for democratic debate (Machin 2013).

\footnotetext{
4 Now that the existence and primary cause of climate change are essentially settled, IPCC working groups II and III are moving beyond a monolithic approach: They are facing a larger number of second-tier questions - for example, regarding the manifestation of climate change in extreme events, in the availability of water and food and on regional scales, as well as the ever-elusive effect of aerosols on climate. WG II has produced a summary of its recent work, which has also helped to place climate change impacts in relation to other drivers/pressures, thereby adding an important component to the discussion.
} 
Much has changed since the late 1980s when the IPCC was established. Starting out with relatively few formalized rules in 1988, the IPCC has gone through three major revisions, in 1993 , 1999, and 2010. ${ }^{5}$ As a response to the controversial release of climate scientists' e-mails (the "climategate" affair) and arguments about errors in the IPCC's Fourth Assessment Report (IPCC 2007), the alliance of national scientific academies - the InterAcademy Council(IAC) - was commissioned in March 2010 to conduct an independent evaluation of the procedures and processes of the IPCC. ${ }^{6}$ The IAC focused on processes of assessment and quality assurance rather than on the content and quality of IPCC reports. The events surrounding "climategate" raised important questions about the process of knowledge production rather than seriously challenging the core substance of that knowledge (Hulme 2010). These events showed that in terms of public value it is the social practices and quality of knowledge making that matter as much as the content of the knowledge itself. The council acknowledged that the IPCC therefore has a growing obligation to account for its workings and conclusions, not least because the panel is highly exposed to public scrutiny and effectively operating "under the public microscope" (IAC 2010). Experts have to be responsive to the ways in which scientific knowledge is validated and made authoritative for public use. The IAC also emphasized that in its present form the panel was no longer able to cope adequately with the challenges it faces (IAC 2010, p. 6).

The negotiations over IPCC reform have thus far focused on improving scientific quality by reviewing specific procedures (from the selection of authors and review procedures to the way errors are dealt with in published assessment reports). The issue of public trust is treated as one of effective communication. This attempt at reforming the IPCC has amounted to making existing procedures more transparent for the scientists and nation state representatives already involved. ${ }^{7}$ However, it also means that the panel's work continues to take place "behind closed doors".

Although a perceived lack of public accountability can be regarded as one of the triggers of public controversy following "climategate", there has been no evidence to date of any efforts to establish appropriate mechanisms of disclosure to address it. This narrowing of the outcomes of reform negotiations has been closely associated with the panel's consensus-based decision-making procedures. Whenever matters of negotiation have been contested, consensus-based negotiations have led to a "lowest common denominator" - a minimum outcome accepted by all parties at that time (Rahmstorf 2013). The requirement of unanimity and the orchestration of procedures, however (so runs the argument), leads to the fact that scientific findings and views deviating from the mainstream are systematically ignored or excluded (PBL 2010). It is precisely those reform proposals that go beyond incremental revision of specific procedures and signal a need for structur-

5 www.ipcc.ch/organization/organization_procedures.shtml\#.UQJ7ZXfjEXQ

6 http://reviewipcc.interacademycouncil.net

7 www.iisd.ca/climate/ipcc34 al adaptation, which remain highly contentious and have therefore largely been bracketed out of the intergovernmental negotiations, or else postponed. So far, no debate has ever taken place about the IPCC's relationship to public policy and to its various global "publics" or about its normative commitments in terms of accountability, political representation, and legitimacy.

We argue, however, that "business as usual" and incremental adjustments of the procedures and institutional design are not enough to adequately address novel challenges (IAC 2010). As a result, the IPCC reforms address not so much the causes (such as the perceived lack of public accountability) as merely the symptoms (e.g., the lack of transparency of existing procedures) of the problem.

These difficulties also point to the more profound problem of how climate change issues are framed. The framing of climate change by the IPCC as a universal global risk reinforces the assumption that more and better consensual decision support will lead to public trust and political action. This assumption is not necessarily the solution, but might contribute to the problem of political inertia. Our point is that the IPCC has bought into a very specific framing of "the problem" that has rendered climate policy ineffective and has foreclosed the possibility of public consent. If climate change risks were framed differently, then different forms of political action would open up - in relation, for example, to regional adaptation, local air quality, and energy services for the poor. Opening up the issue of climate change to different ways of framing is part of an enhanced reflexivity and social learning process. To overcome this situation, we suggest that the panel needs to continuously review its own procedures, performance, and underlying assumptions.

The question then is how the panel best can navigate the difficult matter of representation. Is it to be a closed conversation between (accredited) experts and policy-makers? Or do the views of the public matter? It is these choices and normative criteria themselves that, once chosen, must be made explicit and subject to regular deliberation and re-appraisal.

Political relevance: When the IPCC was formed in 1988, it fitted neatly into the UN's multilateral order based on national representation and the search for internationally negotiated solutions. At a time, however, when UN climate multilateralism has lost momentum, the panel now faces the challenge of adjusting to a changing geo-political architecture characterized by a more fragmented, polycentric order in which (climate) governance occurs at more than simply the level of nation states (Ostrom 2010). Given these novel constellations the IPCC reform debate cannot relate only to procedures and management structures to improve the transparency of its processes. It has to also address its broader institutional settings such as the post-Kyoto architecture where policy needs to engage diverse citizens with multiple beliefs, values, and sources of knowledge (Hulme 2014). To maintain its policy relevance, the panel should respond to the changing information needs of its primary audience, such as national governments, and recognize the diverse knowledge needs from a much 
broader group of stakeholders. We contend also that it may not be practicable for one expert panel under sole ownership - that of the world's governments, but operating under the delegated management of the United Nations Environment Programme (UNEP) and the World Meteorological Organization (WMO) - to deliver an exhaustive, fully integrated, universally credible assessment of all relevant climate-change knowledge. The issues facing the world today are probably not going to be resolved by producing yet more mega-global assessments - perhaps it is a larger number of distributed assessments that we need.

Forms of integration and representation: Framing anthropogenic climate change as a global universal risk calls for particular scientific practices of up-scaling and a standardization of approaches (Miller 2004). ${ }^{8}$ Continuing the quest for increasingly integrated and consensus-based decision support information may not be the most beneficial way to inform debates about diverse policy portfolios in politically contested fields such as energy supply and carbon dioxide removal. Here, cultural differences and preferences proliferate, and significant decisions can be taken at much smaller scales than the planet. Focusing on consensus, the IPCC becomes vulnerable to criticism relating to issues where no consensus exists (e.g., biofuels, solar radiation management technologies). The IPCC's emphasis on peer reviewed research to underpin its univocal, consensus-based statements has simultaneously excluded alternative forms of expertise - such as legal reports, which, as a rule, are rarely published in these forums - along with more localized and informal forms of knowledge. ${ }^{9}$ As a response to these shortcomings, the IPCC has introduced new guidelines for the integration of "gray literature" into AR5 (WG I TSU 2010). Integrating, or even aligning, these new areas of knowledge in future assessments may require different procedures - such as extended quality control, expert elicitations, and minority reporting - and different institutional arrangements. Different protocols for expert deliberation across different knowledge domains may be needed as well as greater public transparency about how these protocols work in practice. This is one reason why the IPCC has to be "prized open" and re-constituted to reflect the changing political, social, and cultural worlds in which climate change now circulates.

Public accountability and participation: The events surrounding "climategate" demonstrated that public trust cannot be reduced to a function of the quality of science or the breadth and depth of consensus on science alone, as the IPCC had assumed. They

8 This emerges from an idealized model of policy-making based on neutral scientific advice feeding into political decision-making. The IPCC's decision to present scientific assessments as based on consensus rests upon the assumption that univocal scientific statements are more authoritative in transnational politics than multi-vocal statements.

9 Scientometric studies, for instance, show that references to IPCC reports are skewed towards geophysical sciences and countries of the global North (Vasileiadou et al. 2011). showed that trust in science is related to the performance and persuasive power of the people and institutions who speak for science - and that not all countries interpret or trust the IPCC in similar ways (Hajer 2012). The IPCC's chosen style of risk assessment and communication has also contributed to a unitary approach to representing scientific consensus as a single voice. Not acknowledging or inviting diverse voices to speak will fail to assuage the sense of mistrust. In response, the IPCC plenary has not yet adopted a process of full public disclosure, and it continues to rely upon its existing knowledge-making processes mediated by national delegations. In addition, current discussions about the future of the IPCC continue to be conducted largely behind closed doors, even if the formal positions of countries are somewhat more transparent. It is very likely that in the future the panel will be exposed to scrutiny from more diverse and lively publics and that it will have to respond to forms of distributed or uninvited public participation (Wynne 2007).

Many of the issues we raise are empirically open questions, but it is fair to assume that the IPCC's future performance will depend on how thoroughly it responds to these sorts of challenges.

\section{IPBES: Opening Up to Alternatives}

Prominent voices in the science and policy community have asserted that, in order to tackle the biodiversity crisis, the disconnect between science and policy needs to be overcome by establishing a permanent, globally orchestrated organization akin to the IPCC (DIVERSITAS 2005, Loreau et al. 2006). However, these calls for an "IPCC for biodiversity" have been contested from the start (Görg et al. 2007, Hulme et al. 2011, Perrings et al. 2011, Turnhout et al. 2012). After seven years of intense negotiations the IPBES was formally established in 2012 under the auspices of UNEP (Spierenburg 2012). Instead of simply implementing the IPCC design and procedures, IPBES negotiations explored different options concerning the governance structure of the platform. Overall, the negotiation processes over how to set up the IPBES have been relatively transparent and open. They have involved a broad range of stakeholders and have favored a multidisciplinary expert approach from the beginning. As a result, the scope of these negotiations has been relatively broad and inclusive: for instance, the IPBES agenda has not been restricted to procedures and management structures, as was the case with the IPCC reform agenda, but has included a thorough gap analysis of information needs and the explicit involvement of stakeholders (Koetz et al. 2012). It was enlarged to address the same three challenges as those facing the IPCC:

Political relevance: The IPBES has spent a lot of time and effort aligning itself with a complex governance structure that includes several global agreements and takes account of the need to address the specific regional and local conditions of biodiversity and ecosystem services loss. It also had to identify the knowledge needs 
and gaps to be addressed by this novel expert platform. During the scoping process it was recognized that producing yet another comprehensive and global assessment report on the state of biodiversity and ecosystem services science, based on the Millennium Ecosystem Assessment (MEA 2005), will not meet the needs of its diverse audiences and will fail to support localized action on the ground. In order to enhance its political relevance, the IPBES decided to produce a global but multi-scale assessment and to complement this process by setting up three additional working areas, namely knowledge generation, capacity building, and policy support.

Forms of integration and representation: In contrast to the IPCC, the IPBES accords greater value to regional and local scales. This refers not only to the scale of assessments but also to the inclusion of local and indigenous knowledge, building on the strong voice and involvement of the according stakeholder groups in global deliberations, especially on the Convention on Biological Diversity ( $C B D$ ). Thus, instead of taking scientific, peer-reviewed knowledge as the gold standard, the IPBES plenary discussed the relevance and credibility of different forms and sources of knowledge and experience in relation to serving the broad range of tasks the IPBES decided to tackle. As a result, the IPBES agreed on establishing a task force for strengthening the quality of indigenous peoples' participation in the platform's deliverables. It has also recognized that an exclusive focus on economic valuation is not an adequate response to the complexity of biodiversity loss. It has taken on board a differentiated conceptualization of the values of biodiversity and of its benefits for human well-being. While these commitments signify a willingness to take the value of diverse knowledge systems seriously, the challenge remains how to cope with diversity in practice.

The IPBES has agreed on a conceptual framework that acknowledges the multiplicity of knowledge systems. What is essentially at stake is whether the IPBES can employ mechanisms of standardization and commensuration while at the same time retaining uncertainties, divergent world views, and relevant local and indigenous knowledge (Turnhout et al. 2012). What it seeks to accomplish is to produce a diverse range of possible interventions and policy options using this framework.

Public accountability and participation: The IPBES has its origins in a multi-stakeholder initiative. At the same time, it was established as an intergovernmental platform. Much like the IPCC, governments participate in the plenary sessions (see figure), where decisions about the work program, rules and procedures are made and reports are accepted, adopted and approved. In contrast to the IPCC, in the case of the IPBES many stakeholders asked to be recognized as equal partners in all important aspects of the work of the IPBES, including the nomination of experts (Carino 2013). These requests imply an expansion of stakeholders' rights and their legal status. They are moving far beyond the observer role usually granted to non-governmental organizations in intergovernmental settings under the UN. However, national governments with decision-making authority in the IPBES plenary are reluctant to adopt a stakeholder engagement strategy that implies enhancing the role of stakeholders through their participation in all IPBES processes (Opgenoorth et al. 2014).

The IPBES still struggles to implement innovative options to meet the demands of scientists, politicians, and diverse global publics; thus resembling other approaches to improve the science-policy interface on the topic biodiversity (Spierenburg 2012, Neßhöver et al. 2013). It remains an open question whether and how these demands will be incorporated into the rules and procedures of the IPBES. Notwithstanding the acknowledgement of different types of knowledge and the need for broad stakeholder involvement, the negotiations on how to set up a stakeholder engagement strategy are not yet completed and the role and legal status of stakeholders has not yet been established (Opgenoorth et al. 2014). Upcoming negotiations will determine whether or not the IPBES is capable of engaging with issues of plural knowledge systems, local voices, and diverse forms of public engagement.

The institutional setting of the UN system does not favor openness to alternative design options. Often, IPBES negotiations turn into bargaining processes about the allocation of power and authority. Key players then realize that they may gain (or lose) epistemic and political authority as a result of being reconfigured around this new platform. As a consequence, IPBES negotiations reveal a feature that also characterizes IPCC negotiations inside the plenary (Beck 2012). Even if governments are willing to delegate authority to global expert organizations, they still try to safeguard their influence by controlling processes such as the nomination of experts or the drafting of summaries for policy makers. By restricting the diversity of voices and closing down the range of options open to negotiation, consensus-based knowledge assessment procedures constrain the room for maneuver and limit innovation. They reinforce incremental change as the default mode of evolution, rather than encouraging more dynamic forms of organizational learning.

\section{Conclusions}

The examples of the IPCC and the IPBES indicate that there is a need and an opportunity to reflect on the very purpose and underlying rationale of global expert organizations. The IPCC has been hegemonic - as the persistent rhetoric surrounding the IPBES has shown (such as the calls for "an IPCC for biodiversity") (Loreau et al. 2006). However, there is no such thing as a one-sizefits-all model for the governance of expertise. The argument we have made is twofold: first, as the IPCC experience shows, assessment panels must themselves change over time, sometimes radically; and second, those involved in each new domain for which an expert assessment body is convened must do the job of institutional design mostly from scratch - different assessment processes should be designed accordingly to address context-specific demands for knowledge(s). 
Even if we cannot provide substantive recommendations for particular cases, we can nonetheless highlight a number of generic procedural design principles. An overly narrow focus on changing procedures and management structures - as has been adopted by the IPCC following the IAC review - is not sufficient to the tasks and challenges these organizations will face in the future. Instead, a more ready and open acknowledgment of such organizations' normative commitments and alternative institutional design options may help to render expertise more responsive and effective. The reflexive turn implies an opening up of perceptual horizons to recognize different models of "ownership" (state/ non-state/UN) and to legitimize multiple knowledges and diverse standards of evaluation. This kind of active "opening up" of political space and a "pluralist" approach to knowledge offer a more robust basis for the governance of expertise.

Of course, the move towards reflexive expertise is not new. Neither can it solve all difficulties nor can it automatically guarantee better results. Constraints will remain in terms of available capacity to address emerging tasks, trade-offs between conflicting aims (e. g., between demands for broad participation and for scientific integrity), and political expectations that may constrict the selection and implementation of institutional design options. However, throughout all processes of negotiation and review it is crucial to confront the reality of uncertainties, political antagonisms, and power struggles in order to render them open to change, rather than simply ignoring them. To do justice to the issues we raise above it is necessary to challenge the underlying assumptions such as the ideal of neutral scientific advice - and institutional dynamics - such as intergovernmental status and consensus-based procedures - that drive such organizations toward premature closure or even organizational paralysis. The IPBES is a promising example of what may be achieved in terms of openness; yet its institutional design (e.g., issues of accountability towards observers such as scientific organizations) and its procedures (e.g., stakeholder participation in knowledge assessments) have not yet been fully adopted and its workings will need continuous monitoring and organizational review (Turnhout et al. 2012, Opgenoorth et al. 2014). ${ }^{10}$

10 In order to fully assess the organizational reflexivity and adaptability, one has to take into account that both organizations differ when it comes to the degree of the institutionalization of their governance structures. While procedures and the final governance structures of the IPBES are still under negotiation, the IPCC has evolved from a small informal network of experts to a large intergovernmental organization, which has established a complicated set of formalized rules of procedures. The strategy of formalizing procedures contributes towards a greater coherence of governance structures and therefore increases the political robustness of the organization. The increasing standardization, however, contributes to reinforcing bureaucracy and the inertia. It is still open how the IPBES governance structure may differ from the IPCC arrangement when it is finally set up.

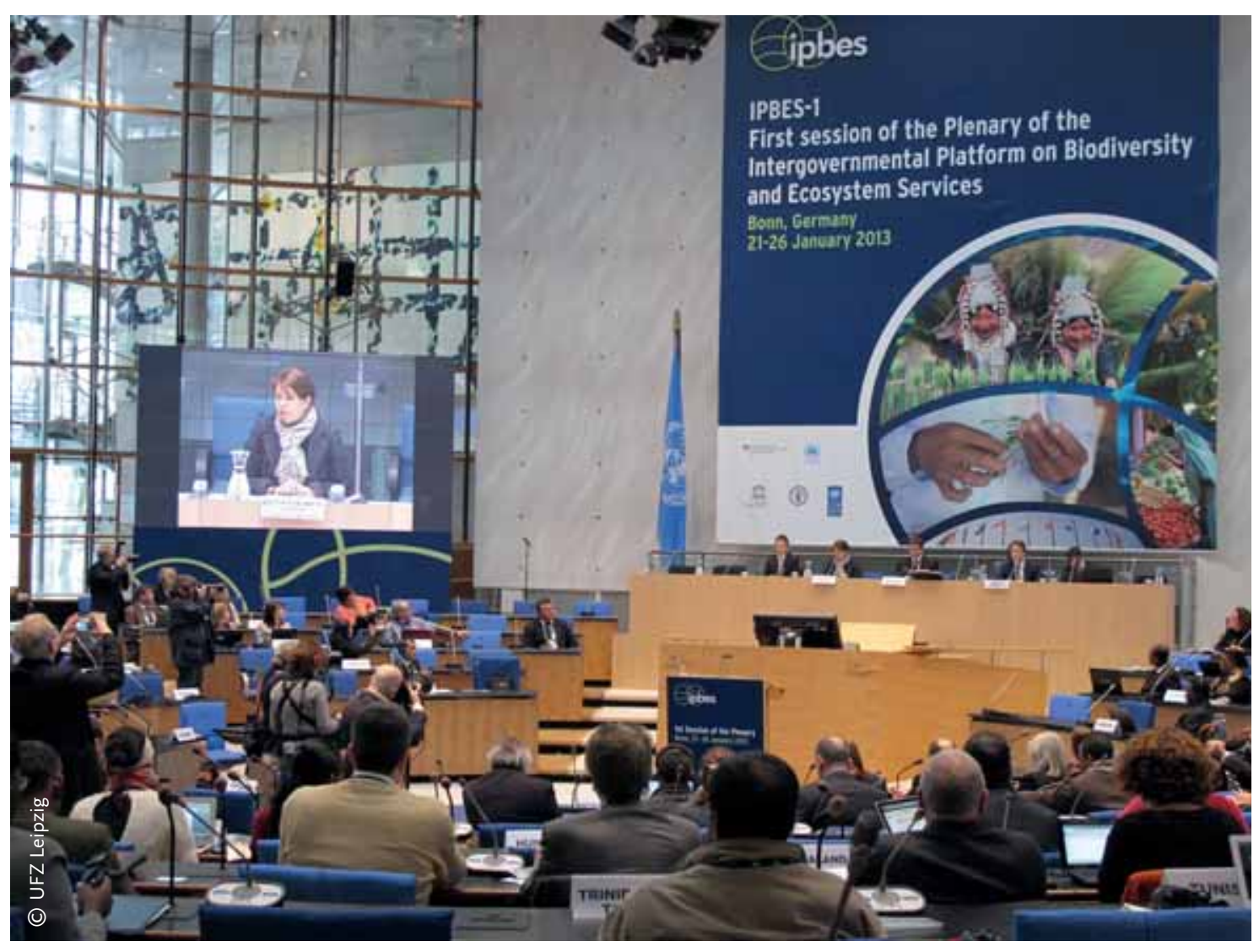

\section{FIGURE:}

In the IPBES plenary sessions the work program rules and procedures are decided upon and reports are accepted, adopted and approved. In contrast to the IPCC, in case of the IPBES many stakeholders asked to be recognized as equal partners in all processes, not as mere process observers. However, since national governments with decision-making authority in the IPBES plenary are reluctant, the negotiations on a stakeholder engagement strategy have not been completed. The picture was taken during the first session of the IPBES plenary in January 2013 in Bonn. 
This reflexive turn aims to generate a broad range of visions, pathways, and ways of responding that leave room for choice. For this reason we encourage experimentation with new forms and formats of governing expertise by bringing in largely neglected sources of knowledge, voices and options. The more perspectives are available to political actors, the wider the range of policy options that will be conceivable. A more reflexive and inclusive form of governing environmental expertise, based upon a more plural and participatory normative and epistemic framework, can make knowledge about environmental change more useful and increase politicians' and the general public's willingness to adopt new policies. Recognizing competing ways of seeing and knowing nature and society may contribute not only towards mapping out possible future trajectories of environmental change but also towards investigating a wider set of policy choices and constructing alternative framings and visions for society in the future.

\section{References}

Beck, S. 2012. Between tribalism and trust: The IPCC under the "public microscope". Nature and Culture 7/2: 151-173.

Carino, J. 2013. Statement delivered by Joji Carino from the Forest Peoples Programme on behalf of the International Indigenious Forum on Biodiversity and Ecosystem Services at IPBES-2. www.ipbes.net/images/International\% 20Indigenous\%20Forum\%20on\%20Biodiversity\%20and\%20Ecosystem\% 20Services\%5B1\%5D-2.pdf (accessed May 6, 2014).

DIVERSITAS. 2005. Oaxaca Declaration on Biodiversity. www.diversitasinternational.org/activities/open-science-conferences/osc1-1/oaxacadeclaration (accessed May 6, 2014).

Ford, J. D., W. Vanderbilt, L. Berrang-Ford. 2012. Authorship in IPCC AR5 and its implications for content: Climate change and indigenous populations in WG II. Climatic Change 113/2: 201-213.

Görg, C. et al. 2007. International science-policy interfaces for biodiversity governance. Needs, challenges, experiences. A contribution to the IMoSEB consultative process. Leipzig: Helmholtz Centre for Environmental Research - UFZ. www.ufz.de/export/data/1/28241_leipzig_workshop_ report_final25406.pdf (accessed May 6, 2014).

Hajer, M.A. 2012. Living the winter of discontent: Reflections of a deliberative practitioner. In: Futures of modernity: Challenges for cosmopolitical thought and practice. Edited by M. Heinlein, C. Kropp, J. Neumer, A. Poferl, R. Römhild. Bielefeld: transcript. 77-94.

Hulme, M. 2010. Problems with making and governing global kinds of knowledge. Global Environmental Change 20/4: 558-564.

Hulme, M. 2014. Streitfall Klimawandel. Warum es für die größte Herausforderung keine einfachen Lösungen gibt. München: oekom.

Hulme, M. et al. 2011. Science-policy interface: Beyond assessments. Science 333/6043: 697-698.

IAC (InterAcademy Council). 2010. Climate change assessments: Review of the processes and procedures of the IPCC. Amsterdam: IAC.

IPCC (Intergovernmental Panel on Climate Change). 2007. Climate change 2007: Synthesis report. Contribution of working groups I, II and III to the Fourth Assessment Report of the IPCC. Geneva: IPCC.

Jamison, A. 2010. Climate change knowledge and social movement theory. Wiley Interdisciplinary Reviews - Climate Change 1/6: 811-823.

Jasanoff, S. 2012. Science and public reason. New York: Routledge.

Koetz, T., K. N. Farrell, P. Bridgewater. 2012. Building better science-policy interfaces for international environmental governance: Assessing potential within the Intergovernmental Platform for Biodiversity and Ecosystem Services. International Environmental Agreements: Politics, Law and Economics 12/1: 1-21.

Lidskog, R., G. Sundqvist (Eds.). 2011. Governing the air. The dynamics of science, policy, and citizen interaction. Cambridge, MA: MIT Press.
Lövbrand, E. Forthcoming. Knowledge and the environment. In: Advances in international environmental politics. Edited by M. M. Betsill, K. Hochstetler, D. Stevis. Basingstoke: Palgrave Macmillan.

Loreau, M. et al. 2006. Diversity without representation. Nature 442/7100: $245-246$.

Machin, A. 2013. Negotiating climate change: Radical democracy and the illusion of consensus. London: Zed Books.

MEA (Millennium Ecosystem Assessment). 2005. Ecosystems und human well-being: Synthesis. Washington, D.C.: Island Press.

Miller, C. 2004. Resisting empire: Globalsim, relocalization, and the politics of knowledge. In: Earthly politics. Local and global in envrionmental governance. Edited by S. Jasanoff, M. L. Martello. Cambridge, MA: MIT Press. 81-102.

Miller, C. 2009. Epistemic constitutionalism in international governance: The case of climate change. In: Foreign policy challenges in the $21^{\text {st }}$ century. Edited by M. Heazle, M. Griffiths, T. Conley. Cheltenham: Edward Elgar.

Neßhöver, C. et al. 2013. Improving the science-policy interface of biodiversity research projects. GAIA 22/2: 99-103.

Opgenoorth, L., S. Hotes, H. Mooney. 2014. IPBES: Biodiversity panel should play by rules. Nature 506/7487: 159

Ostrom, E. 2010. Polycentric systems for coping with collective action and global environmental change. Global Environmental Change 20/4: 550-557.

PBL (Netherlands Environmental Assessment Agency). 2010. Assessing an IPCC assessment. An analysis of statements on projected regional impacts in the 2007 report. The Hague: PBL. www.pbl.nl/sites/default/files/cms/ publicaties/500216002.pdf (accessed May 6, 2014).

Perrings, C., A. Duraiappah, A. Larigauderie, H. Mooney. 2011. The biodiversity and ecosystem services science-policy interface. Science 331/6021: $1139-1140$.

Prins, G. et al. 2010. The Hartwell Paper: A new direction for climate policy after the crash of 2009. Oxford, UK: Institute for Science, Innovation \& Society, University of Oxford

Rahmstorf, S. 2013. Der neue IPCC-Klimabericht. SciLogs, September 23, 2013. www.scilogs.de/klimalounge/der-neue-ipcc-klimabericht (accessed May 6, 2014)

Reisinger, A. 2011. Interdisciplinarity: Are we there yet? An editorial comment. Climatic Change 108/1-2: 23-30.

SAB (Scientific Advisory Board). 2014. UN Scientific Advisory Board convened for the first time - in Berlin. www.sab-2014-berlin.de (accessed May 6, 2014).

Spierenburg, M. 2012. Getting the message across: Biodiversity science and policy interfaces. A Review. GAIA 21/2: 125-134.

Stirling, A. 2010. Keep it complex. Nature 468/7327: 1029-1031.

Stocker, T. F. 2013. Adapting the assessments. Nature Geoscience 6/1: 7-8.

Turnhout, E., B. Bloomfield, M. Hulme, J. Vogel, B. Wynne. 2012. Conservation policy: Listen to the voices of experience. Nature 488/7412: $454-455$.

Vasileiadou, E., G. Heimeriks, A. C. Petersen. 2011. Exploring the impact of IPCC assessment reports on science. Environmental Science and Policy 14/8: 1052-1061.

WG I TSU (Working Group I Technical Support Unit). 2010. General guidance on the use of literature in IPCC reports. Bern: WG I TSU. www.ipccwg1.unibe.ch/guidancepaper/AR5GuidanceNotes_Literature.pdf (accessed May 6, 2014)

Wynne, B. 2007. Public participation in science and technology: Performing and obscuring a political-conceptual category mistake. East Asian Science, Technology and Society 1/1: 99-110.

Submitted March 14, 2014; revised version accepted May 6, 2014 


\section{Dr. Silke Beck}

Alejandro Esguerra

both: Helmholtz Centre for Environmental Research - UFZ,

Department of Environmental Politics, Leipzig, Germany

\section{Maud Borie}

\section{Dr. Jason Chilvers}

both: University of East Anglia, School of Environmental Sciences, Norwich, United Kingdom

\section{Prof. Dr. Christoph Görg}

Helmholtz Centre for Environmental Research - UFZ,

Department of Environmental Politics, Leipzig, Germany, and

University of Kassel, Faculty of Social Sciences, Kassel, Germany

\section{Dr. Katja Heubach}

Dr. Elisabeth Marquard

Dr. Carsten Neßhöver

all: Helmholtz Centre for Environmental Research - UFZ,

Department of Conservation Biology, Leipzig, Germany

\section{Prof. Mike Hulme}

King's College London, Department of Geography,

London, United Kingdom;

Member of the Scientific Advisory Board of GAIA

\section{Prof. Rolf Lidskog}

Örebro University, Center for Urban and Regional Studies, Örebro, Sweden

Prof. Eva Lövbrand

Linköping University, Centre for Climate Science and Policy Research,

Department of Thematic Studies: Water and Environment, Linköping, Sweden

Prof. Clark Miller

Arizona State University, Consortium for Science, Policy \& Outcomes,

Arizona, USA

\section{Dr. Tahani Nadim}

Museum für Naturkunde Berlin, Berlin, Germany

PD Dr. Josef Settele

Helmholtz Centre for Environmental Research - UFZ,

Department of Community Ecology, Leipzig, Germany, and

German Centre for Integrative Biodiversity Research (iDiv), Leipzig, Germany

Prof. Esther Turnhout

Wageningen University, Forest and Nature Conservation Policy Group, Wageningen, The Netherlands

Prof. Eleftheria Vasileiadou

Eindhoven University of Technology, School of Innovation Sciences,

Eindhoven, The Netherlands

This article has been written by practitioners participating in global assessments, such as those issued by the IPCC and the IPBES, and social scientists working on science-policy interactions. It builds on the expert forum Nested Networks: Between wishful thinking, empirical evidence and practical relevance, held in Leipzig, Germany, in 2013: www.ufz.de/index.php?de=19865. The picture shows the expert forum's participants, many of them being co-authors of this article.

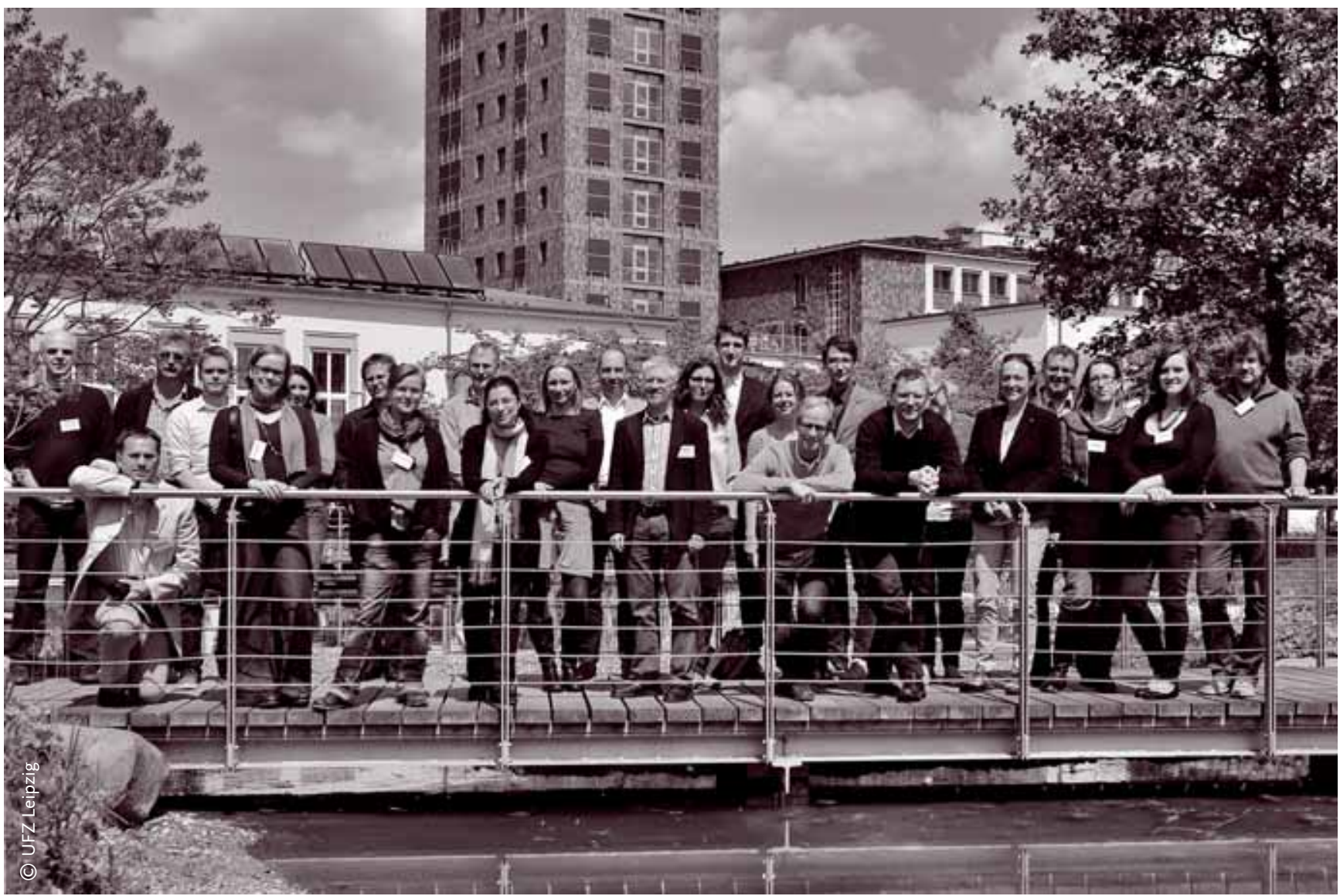

